\title{
Phencyclidine Measurement
}

National Cancer Institute

\section{Source}

National Cancer Institute. Phencyclidine Measurement. NCI Thesaurus. Code C74694.

The determination of the amount of phencyclidine present in a sample. 